\title{
WYBRANE ASPEKTY TEKSTÓW JEDNOLITYCH SAMORZĄDOWYCH AKTÓW PRAWA MIEJSCOWEGO
}

\begin{abstract}
Streszczenie. Praktyka wielokrotnego nowelizowania aktu normatywnego rodzi problemy w ustaleniu obowiązującej treści tego aktu. Problemy te eliminować ma instytucja tekstu jednolitego. Niniejsze opracowanie poświęcone zostało wybranym aspektom tej instytucji prawnej w odniesieniu do aktów prawa miejscowego. Przybliża ono regulacje normujące obowiązek ogłaszania tych tekstów, ich charakter prawny, a także zasady eliminowania zaistniałych w nich błędów. Podkreśla się również konieczność dokładania najwyższej staranności przy ich redagowaniu w celu zapobieżenia pojawiania się w obrocie prawnym tekstów jednolitych niezgodnych z obowiązującym stanem prawnym.
\end{abstract}

Słowa kluczowe: tekst jednolity, sprostowanie błędu, prawo miejscowe, zasady techniki prawodawczej, zmiana aktu normatywnego.

Zważywszy na kierunki i charakter działań podejmowanych przez współczesne państwa, nie ulega wątpliwości, iż bardzo intensywnie realizowana jest przez ich organy działalność prawotwórcza. Stwierdzenie to odnieść można również do sfer aktywności organów państwa polskiego. Abstrahując od oceny tego zjawiska, permanentne zmiany w sferze obowiązującego prawa (dotyczy to zwłaszcza wielu dziedzin życia społecznego objętych regulacją administracyjnoprawną) stawiają na porządku dziennym problem jego znajomości przez adresatów norm prawnych, w sferę nieosiaggalnego postulatu przesuwając ideę powszechnej znajomości prawa. $\mathrm{Z}$ uwagi na przedmiot dalszych rozważań istotne jest przy tym podkreślenie, że - upraszczając nieco problem - zmiany w systemie obowiązującego prawa dokonywane są w drodze wprowadzania do tego systemu nowych aktów normatywnych ${ }^{1}$ bądź też $\mathrm{w}$ drodze nowelizowania (zmiany) aktów już w tym systemie obowiązujących. Niebagatelne znaczenie mają również zmiany związane z aktywnością innych (niż organy tworzące prawo) organów władzy publicznej, przede wszystkim zaś organów kontroli prawa (w szczególności sądów administracyjnych i Trybunału Konstytucyjnego).

Zasygnalizowane zjawisko, skutkujące praktycznymi trudnościami w dotarciu i ustaleniu treści obowiązującego w określonym momencie prawa, stwarza po stronie adresatów regulacji prawnych (należy tu podkreślić - zarówno podmiotów

* Uniwersytet Łódzki, Katedra Prawa Administracyjnego i Nauki Administracji, Zakład Prawa Administracyjnego,mlewicki@wpia.uni.lodz.pl.

${ }^{1}$ Mogą to być przy tym akty normujące dziedziny wcześniej nieobjęte regulacją prawną lub akty zastępujące wcześniej obowiązujące w danej dziedzinie regulacje. 
prywatnych, jak i organów władzy publicznej stanowiących, stosujących i egzekwujących prawo) swoiście rozumiane zapotrzebowanie na stworzenie i sprawne funkcjonowanie rozwiązań i instytucji dostęp taki zapewniających.

Nie ulega wạtpliwości, iż w istotny sposób potrzebę tę zaspokajają różnego rodzaju komercyjne systemy informacji prawnej (np. Lex, Legalis) zapewniające ich użytkownikom informację o aktualnej (jak również obowiązującej w innym czasie) wersji aktu normatywnego. Niezależnie jednak od praktycznych walorów i faktycznego zakresu ich wykorzystywania podkreślić należy nieurzędowy (nieformalny), a w konsekwencji nieusankcjonowany przez organy władzy publicznej charakter uzyskanych za pośrednictwem tych systemów informacji, w szczególności zaś ujednoliconych tekstów aktów normatywnych, czyli tekstów aktów normatywnych uwzględniających dokonane w nich zmiany.

W przeciwieństwie do nieurzędowego i nieoficjalnego charakteru wspomnianych wyżej ujednoliconych tekstów aktów normatywnych ${ }^{2}$ zasadniczo inny charakter prawny ma instytucja tekstu jednolitego, której ratio stanowi podanie do publicznej wiadomości (poprzez ogłoszenie w dzienniku urzędowym) aktualnej (na dzień ogłoszenia tego tekstu) treści aktu normatywnego, który został zmieniony. Zważywszy na kształtujące tę instytucję prawne uwarunkowania, a także towarzyszące im wypowiedzi nauki prawa oraz orzecznictwo sądowe, przyjąć należy, iż tekstem jednolitym jest ogłoszony przez upoważniony do tego organ władzy publicznej tekst zmienionego wcześniej aktu normatywnego, którego treść uwzględnia dokonane w nim zmiany, które nastapily od momentu wydania pierwotnego tekstu aktu normatywnego albo od momentu ogłoszenia jego ostatniego tekstu jednolitego (zob. Błachut, Gromski, Kaczor 2008, 116; Wierczyński 2008, 255; Wronkowska, Zieliński 2012, 206). Szczególny charakter tak rozumianego tekstu jednolitego wyraża się przede wszystkim w jego prawnej doniosłości, widocznej zwłaszcza w kontekście prawnych skutków jego ogłoszenia. Uprzedzając dalsze rozważania, zasygnalizować można tylko, że zasadniczo niekwestionowana jest, zarówno w literaturze przedmiotu, jak i w orzecznictwie sądowym, teza, że tekst jednolity aktu normatywnego objęty jest domniemaniem autentyczności wyrażającym się w przyjęciu, iż kształt aktu normatywnego, w jakim został on ogłoszony w tekście jednolitym, jest kształtem nadanym mu przez prawodawcę i w związku z tym od momentu jego ogłoszenia stanowi on wyłączny punkt odniesienia do stosowania aktu normatywnego (Wronkowska, Zieliński 2012, 206, 211; Wierczyński 2008, 265)3. Już choćby z tego względu kwestią niezwykle istotną jest ukształtowanie standardów (zasad) opracowywania tekstów jednolitych

${ }^{2}$ Walor ten mają teksty opracowywane przez podmioty prywatne, ale również (jeżeli odbywa się to poza prawem uregulowaną formułą ogłaszania tekstu jednolitego) podmioty funkcjonujące w sferze władzy publicznej.

${ }^{3}$ Kwestia domniemania autentyczności tekstów jednolitych pojawia się również w orzecznictwie Trybunału Konstytucyjnego - zob. np. wyrok TK z 29 stycznia 1997 r., K 18/96, OTK 1997, nr 1, poz. 2. Jedynym bodaj autorem, który w tym zakresie wyraził pogląd odmienny, jest P. Radziewicz, zdaniem którego tekst jednolity nie jest tekstem autentycznym, ponieważ normy zawarte w tym tekście 
zapewniających ich adekwatność wobec obowiązującego stanu prawnego i - co oczywiste - ich znajomość oraz rzetelne stosowanie przez podmioty w tym zakresie właściwe. $\mathrm{W}$ tym kontekście szczególnego znaczenia nabiera również problem istnienia i skuteczności mechanizmów kontroli ogłaszanych tekstów jednolitych aktów normatywnych. Niewatpliwą, w przekonaniu autora, potrzebę istnienia takich mechanizmów uzasadnia - bynajmniej nie teoretyczna - sytuacja pojawienia się w obrocie prawnym wadliwie zredagowanego tekstu jednolitego, nieodzwierciedlającego aktualnej treści aktu normatywnego.

W obowiązującym stanie prawnym regulacje w sposób bezpośredni kształtujące instytucję tekstu jednolitego nie są nazbyt rozbudowane. Zasadniczo wyczerpują się one w kilku przepisach zawartych w dwóch aktach normatywnych. Pierwszym jest ustawa z dnia 20 lipca 2000 r. o ogłaszaniu aktów normatywnych i niektórych innych aktów prawnych (u.o.a.n.), drugim zaś rozporządzenie Prezesa Rady Ministrów z dnia 20 czerwca 2002 r. w sprawie „Zasad techniki prawodawczej” (ZTP), a w istocie określający zasady techniki prawodawczej załącznik do tego aktu. Przedmiot i ograniczone ramy opracowania usprawiedliwiają przy tym z jednej strony przedstawienie ich w sposób w miarę ogólny, z drugiej zaś zrelatywizowany do jednego z rodzajów aktów normatywnych powszechnie obowiązujących, jakimi są akty prawa miejscowego stanowione przez organy jednostek samorządu terytorialnego (j.s.t.) - zwane dalej samorządowymi aktami prawa miejscowego. Na podkreślenie już w tym miejscu zasługuje, że w świetle samorządowych ustaw ustrojowych (u.s.g., u.s.p., u.s.w.) w kompetencje prawotwórcze wyposażone zostały przede wszystkim mające charakter kolegialny organy stanowiące tych jednostek (zob. art. 41 ust. 1 u.s.g., art. 42 ust. 1 u.s.p. i art. 89 ust. 1 u.s.w.) i to akty stanowione przez te organy stanowiły będą podstawowy kontekst rozważań ${ }^{4}$.

Regulacje dotyczące tekstów jednolitych zawarte są przede wszystkim $\mathrm{w}$ art. $16 \mathrm{i}$ art. 18 u.o.a.n. Pierwszy normuje podmiotowe i przedmiotowe aspekty obowiązku ogłaszania tekstów jednolitych aktów normatywnych, drugi zaś kwestię sprostowania błędów w tekście jednolitym.

Przyjmując założenie, że przedmiotem regulacji zawartej w art. 16 u.o.a.n. jest problematyka ogłaszania tekstów jednolitych aktów normatywnych i ograniczając ustalenia do samorządowych aktów prawa miejscowego, dokonać można kilku podstawowych ustaleń.

Po pierwsze, treścią czynności, których podejmowanie przez właściwe podmioty władzy publicznej zostało w tym przepisie uregulowane, jest ogłoszenie

obowiązują nie dlatego, że znalazły się w tekście jednolitym, ale z mocy pierwotnej promulgacji w tych dziennikach urzędowych, których treść złożyła się później na tekst jednolity (Radziewicz 2002, 59).

${ }^{4} \mathrm{~W}$ związku z tym pominięta zostanie problematyka ogłaszania tekstów jednolitych przepisów porządkowych wydawanych przez organy wykonawcze gmin i powiatów (kompetencje prawotwórcze tych organów przewidują art. 41 u.s.g. oraz art. 42 u.s.p.) - zważywszy na prawne uwarunkowania stanowienia tych przepisów przez organy wykonawcze problem ogłaszania ich tekstów jednolitych i tak miałby charakter czysto teoretyczny. 
tekstu jednolitego aktu prawa miejscowego, a zatem tekstu znowelizowanego aktu prawa miejscowego. Uprzedzając dalsze uwagi podkreślić należy, iż już to sugeruje nienormatywny (nieprawotwórczy) charakter samej czynności, a w konsekwencji i stanowiącego jej przedmiot tekstu jednolitego.

Po drugie, stylistyka analizowanej regulacji pozwala przyjąć, iż ogłoszenie tekstu jednolitego aktu prawa miejscowego stanowi z woli ustawodawcy przedmiot obowiązku prawnego (a nie uprawnienia) aktualizującego się po spełnieniu określonych przesłanek.

Po trzecie, podmiotami obowiązku ogłaszania tekstów jednolitych samorządowych aktów prawa miejscowego są, w świetle art. 16 ust. 3, jako organy właściwe do ich wydawania, organy stanowiące j.s.t.

Po czwarte, przesłanka, której spełnienie aktualizuje obowiązek ogłoszenia tekstu jednolitego, jest nowelizacja aktu prawa miejscowego (art. 16 ust. 3 zd. drugie). To prima facie oczywiste założenie uzasadniające praktyczną zasadność i doniosłość opracowywania skonsolidowanych tekstów aktów normatywnych (tekstów ujednoliconych, tekstów jednolitych) komplikuje fakt, iż, jak się wydaje, pojęcie nowelizacji aktu prawa miejscowego nie obejmuje swoim zakresem wszystkich zdarzeń prawnych, których zaistnienie skutkuje zmianą tego aktu, a w konsekwencji rodzi potencjalne problemy z ustaleniem jego aktualnej treści. Poza zmianą bowiem stanowiąca rezultat klasycznej nowelizacji, polegającej na uchyleniu niektórych przepisów aktu normatywnego, zastapieniu niektórych jego przepisów przepisami o innej treści lub brzmieniu bądź dodaniu do niego nowych przepisów ${ }^{5}$, a zatem będącą rezultatem świadomego i zamierzonego działania prawodawcy nakierowanego na zmianę wcześniej wydanego przez siebie aktu, wskazać można sytuacje, w których do zmiany treści aktu prawa miejscowego dochodzi w związku z wydaniem określonego aktu prawnego przez inny podmiot (chodzi tu przede wszystkim o stwierdzenie nieważności aktu prawa miejscowego w części rozstrzygnięciem nadzorczym wydanym przez organ nadzoru nad działalnością j.s.t. bądź też wyrokiem sądu administracyjnego) lub też wygaśnięciem niektórych przepisów aktu prawa miejscowego (zmiana sensu largo) ${ }^{6}$. Bazując na literalnej wykładni art. 16 u.o.a.n., przyjąć jednak można, że nie każda zmiana, ale tylko zmiana będąca rezultatem klasycznej nowelizacji aktualizuje obowiązek ogłoszenia tekstu jednolitego aktu prawa miejscowego przez organ, który go wydał ${ }^{7}$.

${ }^{5}$ Takie rozumienie zmiany (nowelizacji) aktu normatywnego zaczerpnięte zostało z § 82 ZTP zawartego w rozdziale określającym zasady dokonywania zmian w aktach normatywnych i redagowania przepisów zmieniających. W kontekście innych aktów skutkujących zmianą aktu normatywnego można ją określić zmianą sensu stricto.

${ }^{6} \mathrm{~W}$ literaturze przedmiotu o złożoności okoliczności skutkujących zmianą treści aktu normatywnego i sposobie ich odzwierciedlania w tekstach jednolitych pisał A. Malinowski (Malinowski 2016, 9-20).

${ }^{7}$ Nie ogranicza to jednak organu stanowiącego j.s.t. w możliwości ogłoszenia tekstu jednolitego w konsekwencji zmiany jego treści spowodowanej wyłącznie działaniami innych podmiotów. Nie będzie to jednak wynik realizacji obowiązku wynikającego $\mathrm{z}$ art. 16 ust. 3 u.o.a.n. 
Po piąte, momentem powstania obowiązku ogłoszenia tekstu jednolitego jest znowelizowanie aktu normatywnego, co należy wiązać $\mathrm{z}$ wejściem w życie przepisów zmieniających ten akt, nie zaś ich ogłoszeniem, a tym bardziej podjęciem uchwały je zawierającej.

Po szóste, obowiązek ogłoszenia tekstu jednolitego należy zrealizować w terminie 12 miesięcy od jego powstania (a zatem wejścia w życie przepisów zmieniających). Zasygnalizować należy przy tym, że w związku z brakiem ustanowienia jakichkolwiek skutków niedopełnienia analizowanego obowiązku we wskazanym terminie przyjąć należy, iż ma on charakter instrukcyjny (porządkowy).

Po siódme, formą, jaka przewidziana została dla realizacji obowiązku ogłoszenia tekstu jednolitego, jest obwieszczenie. Nie rozwijając w tym miejscu zagadnienia istoty i charakteru prawnego tekstu jednolitego (a w konsekwencji i obwieszczenia w tej sprawie), podkreślić jednak należy, iż forma obwieszczenia jednoznacznie wskazuje i podkreśla nienormatywny charakter kompetencji organu ogłaszającego tekst jednolity i obwieszczenia w tej sprawie. Ogłoszenie takiego tekstu, postrzegane jako urzędowa i oficjalna informacja o aktualnym kształcie aktu normatywnego, stanowić powinno wyłącznie rezultat działań o charakterze techniczno-redakcyjnym podjętych w oparciu o reguły redagowania tekstów jednolitych przez podmiot właściwy w tym przedmiocie 9 .

Po ósme, obwieszczenie w sprawie ogłoszenia tekstu jednolitego aktu prawa miejscowego podlega ogłoszeniu w dzienniku urzędowym, w którym ogłoszony

${ }^{8}$ Ustawodawca nie przewiduje żadnych bezpośrednich konsekwencji zarówno w płaszczyźnie samej kompetencji organu właściwego w tym zakresie (w postaci chociażby jej wygaśnięcia czy też przejścia na inny podmiot), jak i skierowanych do bezczynnego organu.

${ }^{9}$ Przedmiot oraz ograniczone ramy opracowania nie pozwalają rozwinąc tego wątku szerzej, choć wspomnieć należy, iż w praktyce ogłaszania tekstów jednolitych samorządowych aktów prawa miejscowego nie zawsze mamy do czynienia ze stosowaniem formy przewidzianej w obowiązującym prawie. Wbrew temu bowiem, co wynika zarówno z u.o.a.n., jak i ZTP, jednoznacznie wskazujących na obwieszczenie jako formę ogłaszania tekstów jednolitych, często stosowaną przez organy stanowiące j.s.t. formą jest uchwała (skądinąd najczęściej o strukturze i treści analogicznej do klasycznych uchwał prawotwórczych - z przepisem o wejściu w życie i ... powierzającym jej wykonanie organowi wykonawczemu), której załącznikiem jest obwieszczenie w sprawie ogłoszenia tekstu jednolitego. Wydaje się, że źródeł takiego stanu rzeczy upatrywać należy przede wszystkim w przekonaniu organów stanowiących, iż wszystkie ich działania muszą przybierać formę uchwały. Podkreślić jednak należy, że na gruncie prawa samorządowego, w kontekście działalności organów stanowiących, pojęcie uchwały rozumiane i stosowane może być w dwóch znaczeniach. Po pierwsze, jako sposób zajmowania stanowiska, wyrażania poglądu przez organ kolegialny (czyli jako metoda działania organu kolegialnego) oraz forma działania zastrzeżona dla określonych spraw, której materialnym substratem i odzwierciedleniem jest akt prawny o określonej strukturze i treści (o tym rozróżnieniu zob. np. Chmielnicki 2013). W tym kontekście ogłoszenie tekstu jednolitego aktu prawa miejscowego w istocie wymaga podjęcia uchwały (w znaczeniu metody działania polegającej na przeprowadzeniu głosowania w tej sprawie, uchwalenia), ale nie powinno przybrać formy uchwały, albowiem obowiązujące przepisy przewidują w tym przypadku formę obwieszczenia. 
został dany akt normatywny, a zatem w związku z art. 13 u.o.a.n., w wojewódzkim dzienniku urzędowym.

Podkreślić w tym miejscu należy, iż poza określeniem obowiązku ogłaszania tekstów jednolitych aktów prawa miejscowego oraz wskazaniem formy jego realizacji, regulacje u.o.a.n. nie normują zasad opracowywania obwieszczeń w sprawie ogłoszenia tekstu jednolitego. Zagadnienia te są przedmiotem postanowień zawartych w dziale III ZTP, którego regulacje, na mocy § 110, znajdują odpowiednie zastosowanie do tekstów jednolitych samorządowych aktów prawa miejscowego. Normują one w szczególności strukturę obwieszczenia o ogłoszeniu tekstu jednolitego, zasady redagowania jego elementów oraz zasady redagowania tekstu jednolitego aktu normatywnego. Z punktu widzenia przedmiotu opracowania, w kontekście postanowień ZTP podnieść należy, jak się wydaje, przede wszystkim dwie kwestie.

Po pierwsze, $\S 100$ a wyraża zasadę, iż tekst jednolity sporządza się według stanu prawnego obowiązującego $\mathrm{w}$ dniu wydania obwieszczenia o ogłoszeniu tego tekstu ${ }^{10}$. Podkreślić w związku z tym należy, że choć zarówno u.o.a.n., jak i ZTP zdają się wiązać instytucję tekstu jednolitego ze zmianami sensu stricto aktów normatywnych, to konieczność sporządzania tych tekstów odzwierciedlających aktualny stan prawny nie pozostawia wątpliwości, że uwzględnione w redakcji tych tekstów muszą być również zmiany sensu largo.

Po drugie, zgodnie z § 101 i nast. ZTP ogłoszenie tekstu jednolitego następuje $\mathrm{w}$ formie obwieszczenia, przy czym tekst jednolity jest załącznikiem do tego obwieszczenia. Co przy tym istotne, tekst jednolity nie jest integralną częścią obwieszczenia w sprawie jego ogłoszenia (taka relacja zachodzi w przypadku załącznika do aktu normatywnego), które pełni rolę swoiście rozumianej zapowiedzi i uzasadnienia tekstu jednolitego o określonej strukturze i funkcji ${ }^{11}$. Konstatacja ta jest ważna o tyle, że pod znakiem zapytania stawia możliwość stosowania przewidzianej w art. 18 u.o.a.n. instytucji sprostowania błędu w tekście jednolitym do obwieszczenia w sprawie jego ogłoszenia. Samo ujęcie tego błędu (jako błędu w tekście jednolitym) zdaje się taką możliwość wykluczać.

Podsumowując ten wątek rozważań stwierdzić należy, iż właściwe zredagowanie tekstu jednolitego aktu normatywnego nie zawsze jest zabiegiem łatwym, a jego ostateczna treść (wynikająca z uwzględnienia zaistniałych zmian)

${ }^{10}$ Przewidziana w tym przepisie możliwość zamieszczenia $\mathrm{w}$ tekście jednolitym również zmian ogłoszonych w dzienniku urzędowym do dnia wydania obwieszczenia, które wejdą w życie po dniu jego wydania, w żaden sposób nie modyfikuje tej zasady. Poza bowiem fakultatywnością podjęcia takiego zabiegu przy okazji redagowania tekstu jednolitego podkreślić należy, iż dodane na tej zasadzie treści, jako nieobowiązujące w wydaniu obwieszczenia, mają wyłącznie walor informacyjny (informują o przyszłych, skądinąd wcale nie pewnych, zmianach w akcie normatywnym).

${ }^{11}$ Jak piszą S. Wronkowska i M. Zieliński, przez ogłoszenie tekstu jednolitego rozumieć należy ogłoszenie obwieszczenia oraz ogłoszenie załącznika do obwieszczenia, którym jest tekst jednolity (Wronkowska, Zieliński 2012, 211). 
oczywista i w rezultacie może rodzić wattpliwości co do jej zgodności z obowiązującym stanem prawnym. Wpływa na to, jak się wydaje, wiele czynników różnej natury, które zwłaszcza w kontekście tekstów samorządowych aktów prawa miejscowego są szczególnie widoczne. Zaliczyć można do nich w szczególności:

- niedostateczną wiedzę na temat istoty i znaczenia instytucji tekstu jednolitego ${ }^{12}$,

- niedostateczną wiedzę na temat zasad ogłaszania tekstów jednolitych (zarówno w zakresie obwieszczeń w tej sprawie, jak i samych tekstów) ${ }^{13}$,

- nieodpowiadające standardom określonym w ZTP dokonywanie zmian w aktach prawa miejscowego ${ }^{14}$,

- trudności w uwzględnianiu przy redagowaniu tekstów jednolitych zmian sensu largo, w szczególności wymagających dokonania pewnych zabiegów interpretacyjnych $^{15}$.

W związku z powyższym, w dziennikach urzędowych ogłaszane mogą być teksty jednolite aktów normatywnych nieodpowiadające standardom ich redagowania, a w konsekwencji również nieodzwierciedlające aktualnej treści aktu normatywnego.

Powracając do dotyczących tekstów jednolitych regulacji zawartych w u.o.a..n., jak już wspomniano, art. 18 u.o.a.n. normuje problematykę sprostowania błędów w tekstach jednolitych. Jego treść daje podstawę do sformułowania następujących tez i wniosków.

Przede wszystkim podkreślić należy, iż w przeciwieństwie do regulacji dotyczącej sprostowania błędów w ogłoszonych tekstach aktów normatywnych

${ }^{12} \mathrm{~W}$ tym (obok wspomnianego braku obowiązywania instrumentów stymulujących), jak się wydaje, w głównej mierze upatrywać należy, iż w bardzo „umiarkowanym” stopniu w j.s.t. realizowany jest obowiązek ogłaszania tekstów jednolitych.

${ }^{13}$ Chodzi tu między innymi o wspomniane już stosowanie niewłaściwej formy ogłoszenia tekstu jednolitego, ale również chociażby o nierzadko „,udane” (o czym świadczy lektura wojewódzkich dzienników urzędowych) przypadki dokonywania w jednej uchwale zmiany aktu normatywnego (w praktyce dotyczy to przede wszystkim statutów j.s.t.) i ogłoszenia jego tekstu jednolitego (stanowiącego załącznik do uchwały zmieniającej).

${ }^{14}$ Jest to związane z praktycznie doniosłą zależnością polegającą na tym, iż właściwie (oczywiście w płaszczyźnie techniczno-redakcyjnej, a nie merytorycznej) dokonywane zmiany znacznie ułatwiają opracowanie tekstu jednolitego zmienionego aktu. Przykładem nierzadko popełnianego błędu przy dokonywaniu zmian, skutkującego trudnościami we właściwej redakcji tekstu jednolitego, jest dokonywanie, wbrew zasadzie określonej w § 89 ZTP, zmian w pierwotnej numeracji jednostek redakcyjnych, która to zasada (jako zasada zachowania numeracji pierwotnego tekstu aktu normatywnego) stosowana być powinna również przy redagowaniu tekstów jednolitych (§ 106 pkt 1 ZTP). Innym problemem jest dokonywanie, zasadniczo niedopuszczalnej, nowelizacji dorozumianej, polegającej na tym, że dawny przepis aktu zastępuje się nowym, nie wskazując jednocześnie dokonywania tej zmiany ( $\$ 86$ ZTP).

${ }^{15}$ Chodzi tu przede wszystkim o problem uwzględniania w tekstach jednolitych aktów prawa miejscowego faktu utraty mocy obowiązującej niektórych przepisów w związku ze zmianą przepisu upoważniającego do wydania tego aktu, co wiążę się z koniecznością znajomości i właściwego zastosowania określonych reguł kolizyjnych. 
(art. 17 u.o.a.n.) ustawodawca expressis verbis określił istotę błędu w tekście jednolitym. Polega ona na niezgodności tekstu jednolitego ogłoszonego w dzienniku urzędowym z tekstem aktu uwzględniającym wszystkie zmiany dokonane do czasu ogłoszenia tekstu jednolitego (art. 18 ust. 1). Dla podkreślenia specyfiki tego ujęcia błędu odnieść je można i porównać z rozumieniem błędu w ogłoszonym tekście aktu normatywnego. Mimo bowiem tego, że art. 17 u.o.a.n. pojęcia tego nie precyzuje, zarówno w literaturze, jak i orzecznictwie za utrwalony uznać można pogląd, iż najogólniej rzecz ujmując, z błędem w rozumieniu tego przepisu i ze skutkami w nim określonymi mamy do czynienia w przypadku rozbieżności (niezgodności) między tekstem aktu normatywnego ogłoszonym w dzienniku urzędowym (któremu przypisuje się walor tekstu autentycznego ${ }^{16}$ ) a stanowiącym podstawę do jego ogłoszenia oryginałem tego tekstu utożsamianym z tekstem, o którym mowa w art. 15 ust. 1 u.o.a.n. (zob. np. Wierczyński 2008, 229 i n.) ${ }^{17}$. Niezależnie od pojawiających się problemów i kontrowersji

${ }^{16}$ Podobnie jak niektórzy autorzy, przyjmuję, że tekstem autentycznym jest tekst aktu normatywnego ogłoszony w dzienniku urzędowym (tak też np. Radziewicz 2002, 56). W tym sensie autentyczność postrzegana jest jako cecha tekstu prawnego mającego walor tekstu obowiązującego adresatów wynikających z niego norm prawnych - nie mogą oni kwestionować ich treści, podnosząc zarzut niezgodności tekstu ogłoszonego z tekstem oryginalnym, a tym bardziej podjętym przez prawodawcę. W konsekwencji za niewłaściwe uważam przypisywanie temu tekstowi domniemania autentyczności. Skoro bowiem tekst ten jest autentyczny, to cecha ta w żaden sposób nie jest wynikiem jakiegokolwiek domniemania (jeżeli ogłoszono akt o treści „A” i uznamy tę treść za treść autentyczna, to nie można domniemywać, że ma on treść „A”). To ostatnie zasadnie można zastosować w twierdzeniu wyrażającym domniemanie oryginalności (zgodności z tekstem oryginalnym) tekstu autentycznego, rozumiane jako domniemanie zgodności (identyczności) tekstu ogłoszonego $\mathrm{z}$ tekstem przekazanym do ogłoszenia. Domniemanie, które nota bene może zostać obalone w drodze ogłoszenia obwieszczenia o sprostowaniu błędu w ogłoszonym tekście aktu prawnego. Co do tekstu oryginalnego z kolei, korzysta on z domniemania zgodności z tekstem podjętym przez prawodawcę (tego domniemania nie da się jednak obalić - konieczne jest dokonanie zmiany aktu). Powyższe uwagi mają znaczenie o tyle, że niektórzy autorzy zdają się nie dostrzegać zasygnalizowanej dystynkcji między autentycznością i domniemaniem autentyczności, niekiedy używając tych pojęć zamiennie (tak zdaje się czynić np. G. Wierczyński w kontekście w pełni zasługujących na aprobatę w zakresie zawartej w nich konstatacji rozważań o ,autentyczności” tekstów ogłoszonych w sposób urzędowy - por. Wierczyński 2015). Dodać przy tym można, iż przypisanie tekstowi ogłoszonemu cechy autentyczności w rozumieniu i ze skutkami zasygnalizowanymi wyżej ma istotne znaczenie chociażby dla określenia charakteru prawnego tekstu jednolitego oraz niektórych aspektów instytucji sprostowania błędów (zarówno w tekstach aktów prawnych, jak i w tekstach jednolitych aktów normatywnych).

${ }^{17}$ Takie, właściwe w przekonaniu autora niniejszego opracowania, rozumienie błędu w kontekście możliwości jego sprostowania na podstawie art. 17 u.o.a.n. wyklucza z zakresu jego normowania zniekształcenia pojawiające się na wcześniejszych etapach procedury prawotwórczej. Egzemplifikacją tego problemu, możliwą do wystapienia szczególnie w przypadku działań organów kolegialnych, jest możliwość powstania rozbieżności między tekstem przyjętym przez organ (tekstem uchwalonym) a tekstem ostatecznie zredagowanym, podpisanym i przesłanym do publikacji (tekstem oryginalnym). Zgodzić należy się jednak z poglądem przewidującym dla usunięcia tej rozbieżności drogę klasycznej nowelizacji aktu normatywnego. 
dotyczących rodzajów mogących wystąpić błędów (chodzi tu o wyróżnianie błędów technicznych i merytorycznych) i związanymi z tym ograniczeniami stosowania instytucji sprostowania w celu ich eliminacji (odnośnie do tych problemów zob. Wierczyński 2008, 229-252; Radziewicz 2002; Garlicki 2002), porównując rozumienie błędu funkcjonujące na gruncie art. 17 i art. 18 u.o.a.n., podkreślić należy jedną podstawową różnicę. Otóż w obu przypadkach tekstami ocenianymi pod kątem ich prawidłowości (bezbłędności w rozumieniu tych przepisów) są teksty ogłoszone w dziennikach urzędowych, a zatem teksty „istniejące”, o strukturze i treści pewnej i powszechnie dostępnej. Zasadniczo inaczej kwestia ta wygląda w odniesieniu do tekstów stanowiących punkt odniesienia i wzorzec służący dokonaniu tej oceny. W przypadku tekstu aktu normatywnego jest nim, jak już wspomniano, tekst oryginalny, o którym mowa w art. 15 u.o.a.n. Jest to zatem również tekst określony, ,istniejący” i w sensie jego treści pewny. Stwierdzenie wystapienia błędu (zarówno o charakterze technicznym, jak i merytorycznym) w tekście ogłoszonym jest zatem zabiegiem relatywnie prostym, bo wynikającym z porównania dwóch istniejących tekstów tego samego aktu normatywnego - przekazanego do ogłoszenia i ogłoszonego (oryginalnego i autentycznego). Natomiast w przypadku tekstu jednolitego status wzorca ma „tekst uwzględniający wszystkie zmiany dokonane do czasu ogłoszenia tekstu jednolitego". Nie jest to w żadnym razie tekst ,istniejący” i przez jakiś podmiot już wcześniej zredagowany (opracowany). Wręcz przeciwnie, jest to tekst idealny w sensie wyobrażonego tekstu właściwie, prawidłowo pod względem merytorycznym, redakcyjnym i temporalnym uwzględniającego $\mathrm{w}$ pierwotnym tekście aktu normatywnego (albo ostatnim ogłoszonym jego tekście jednolitym) zmiany dokonane do czasu ogłoszenia jego tekstu jednolitego ${ }^{18}$ - zmiany wynikające zarówno z klasycznych nowelizacji, jak i zmiany sensu largo ${ }^{19}$. Takiego tekstu

${ }^{18} \mathrm{~W}$ kontekście treści art. 18 u.o.a.n. pojawia się również kwestia waloru oryginału tekstu jednolitego zawartego w załączniku do obwieszczenia w sprawie ogłoszenia tekstu jednolitego. Wyrazić ją można w pytaniu: czy niezgodność tekstu jednolitego ogłoszonego w dzienniku urzędowym $\mathrm{z}$ tekstem oryginalnym zawartym w tym załączniku (przy założeniu, że tekst oryginalny jest prawidłowy), skutkująca ogłoszeniem tekstu niezgodnego z tekstem prawidłowym, daje podstawę do jego sprostowania na podstawie art. 18, czy art. 17. Zdaniem G. Wierczyńskiego (Wierczyński 2016), w tych przypadkach znajduje zastosowanie art. 17 u.o.a.n.

${ }^{19}$ Podobny pogląd podzielają G. Wierczyński (Wierczyński 2016) oraz M. Błachut, W. Gromski, J. Kaczor (Błachut, Gromski, Kaczor 2008, 144). Zasadniczo odmienne stanowisko zajmują w tym względzie S. Wronkowska i M. Zieliński, stwierdzając, że definicja błędu zawarta w art. 18 u.o.a.n. wskazuje jako wzorzec taki tekst, który został przekazany do ogłoszenia przez upoważniony, opracowujący go organ, a błąd ma polegać na niezgodności tekstu ogłoszonego z tym właśnie tekstem (Wronkowska, Zieliński 2012, 230). Nadto zaś, zdaniem Autorów, definicja ta nie obejmuje przypadków, w których tekst przekazany do ogłoszenia nie uwzględnia którejś z tych zmian, które powinny być niewątpliwie uwzględnione (tamże). Pogląd ten nie zasługuje na aprobatę z dwóch powodów. Po pierwsze, wbrew stanowisku Autorów nie znajduje oparcia w literalnej wykładni art. 18 ustawy. Po drugie zaś, jego przyjęcie czyniłoby zupełnie nieracjonalnym powierzenie kompetencji w zakresie prostowania błędów w tekstach jednolitych organom, które je ogłosiły, a nie organom wydającym dzienniki 
po prostu nie ma $^{20}$. Należy jednak podkreślić przy tym, iż komponentami takiego tekstu - wzorca, uwzględnianymi przy jego rekonstrukcji i opracowywaniu, są teksty autentyczne innych aktów normatywnych (w szczególności teksty pierwotnych aktów normatywnych, aktów zmieniających te akty oraz aktów stanowiących podstawy prawne wydawania aktów prawa miejscowego) i innych aktów prawnych (rozstrzygnięć nadzorczych, orzeczeń sądów administracyjnych).

Podsumowując ten fragment rozważań, stwierdzić można, iż w kontekście art. 18 u.o.a.n., o zawierającym błąd (a zatem możliwym do sprostowania) tekście jednolitym aktu prawa miejscowego możemy mówić w związku z wystąpieniem trojakiego rodzaju sytuacji ${ }^{21}$ :

- nieuwzględnienia w nim zmiany (zmian) sensu stricto,

- nieuwzględnienia w nim zmiany (zmian) sensu largo,

- nadania mu treści niewynikającej z tekstu pierwotnego ani żadnej dokonanej przed ogłoszeniem tekstu jednolitego jego zmiany.

Wyróżnienie ostatniej sytuacji jest istotne o tyle, że w dwóch pierwszych chodzi o uwypuklenie przypadków ogłoszenia „nieaktualnego” na dzień ogłoszenia tekstu jednolitego (tekstu nieuwzględniającego wszystkich dokonanych do tego czasu zmian, a jednocześnie ,aktualnego” na określony moment w przeszłości), natomiast ostatnia dotyczy nadania mu treści, jakiej akt ten nie miał nigdy ${ }^{22}$.

W każdym z wyróżnionych przypadków istnieje możliwość (a w kontekście funkcji sprostowania - konieczność, obowiązek) sprostowania tekstu jednolitego. Art. 18 u.o.a.n. określa przy tym, poza pojęciem błędu, formę sprostowania tekstu jednolitego oraz organy właściwe w tych sprawach. Zgodnie z nim błędy prostuje się $\mathrm{w}$ formie obwieszczenia, przy czym strukturę oraz elementy obwieszczenia w sprawie sprostowania błędu w tekście jednolitym określa § 112 ZTP, stosowany odpowiednio $\mathrm{w}$ tych sprawach $\mathrm{w}$ związku $\mathrm{z}$ odesłaniem zawartym $\mathrm{w} \S 113$. Natomiast organem dokonującym sprostowania jest organ, który ogłosił tekst jednolity. Przyjąć w związku z tym należy, iż jest nim organ stanowiący j.s.t. ${ }^{23}$ Nakaz

urzędowe, w których ogłoszone zostały błędne teksty jednolite, co jest przyjęte w przypadku sprostowania dokonywanego na podstawie art. 17. Pogląd ten bez dostatecznego uzasadnienia czyni wyłom w wywodzonej z przepisów o sprostowaniu zasadzie, że błąd prostuje podmiot, który błąd popełnił.

${ }^{20}$ Bez znaczenia jest tu oczywiście fakt istnienia nieurzędowych i nieoficjalnych tekstów ujednoliconych określonego aktu normatywnego.

${ }^{21}$ Oczywiście, sytuacje te mogą występować łącznie (w jednym tekście jednolitym).

${ }^{22}$ Egzemplifikując to w największym skrócie: określona jednostka redakcyjna aktu pierwotnie miała treść „A", dokonane jej nowelizacje nadawały jej kolejno treść „B”, „C” i „D” (ta ostatnia zatem powinna znaleźć się w tekście jednolitym), natomiast w tekście jednolitym jednostka ta ma treść „E”. Na marginesie, odnosząc ten przykład do dwóch pierwszych sytuacji, błąd polegałby na tym, że w tekście jednolitym jednostka ta miałaby treść „B” albo „C”.

${ }^{23}$ Teza ta nie powinna budzić wątpliwości, choć w art. 16 u.o.a.n. pojęcie ogłoszenia tekstu jednolitego pojawia się w dwóch znaczeniach, jako treść obowiązku określonych w tym przepisie organów oraz konwencjonalna czynność organu wydającego dziennik urzędowy. Odnosząc to do samorządowych aktów prawa miejscowego: ogłoszone (w formie wydanego obwieszczenia) przez 
odpowiedniego stosowania $w$ tych przypadkach art. 17 ust. 2 u.o.a.n. skutkuje koniecznością ogłaszania obwieszczeń prostujących błędy w tekstach jednolitych w wojewódzkich dziennikach urzędowych.

Skutkiem ogłoszonego w dzienniku urzędowym obwieszczenia w sprawie sprostowania błędu jest modyfikacja objętej sprostowaniem treści tekstu jednolitego ze skutkami w sferze stosowania (przestrzegania) określonego aktu normatywnego przez jego adresatów. Ustawodawca nie odnosi się przy tym do problemu momentu, od którego dokonane sprostowanie wywołuje skutki prawne. Nie czyni tego, co warte podkreślenia, również i w odniesieniu do sprostowań aktów normatywnych. Odnosząc się do tej kwesti, stwierdzić należy, iż obecne w literaturze przedmiotu oraz orzecznictwie wypowiedzi dotyczące temporalnych aspektów sprostowań formułowane są zasadniczo w kontekście sprostowań w ogłoszonych tekstach aktów prawnych dokonywanych na podstawie art. 17 u.o.a.n. Za powszechnie akceptowany i utrwalony należy uznać w tym przedmiocie pogląd, że mimo formalnie deklaratoryjnego charakteru sprostowania, sugerującego przyjęcie, iż sprostowanie powinno wywierać skutki (ex tunc) od momentu wejścia w życie aktu prostowanego, wzgląd na zasadę zaufania i pewności prawa nakazuje przyjęcie, że sprostowanie nie może wywoływać skutków odnoszonych do czasu sprzed ogłoszenia obwieszczenia w tej sprawie, a w konsekwencji braku podstaw do zastosowania vacatio legis wywiera ono skutki od dnia jego ogłoszenia (ex nunc) (Wierczyński 2008, 251-252; Błachut, Gromski, Kaczor 2008, 145-146; Wronkowska 1996, 106) ${ }^{24}$. Pogląd ten należy podzielić.

$\mathrm{W}$ przekonaniu autora niniejszego opracowania pogląd ten nie znajduje jednak zastosowania do sprostowania błędu w tekście jednolitym ogłaszanego na postawie art. 18 u.o.a.n., które powinno wywoływać skutki od dnia dokonania nieuwzględnionej lub błędnie uwzględnionej zmiany w akcie normatywnym (ex tunc). Uzasadniając to stanowisko, odwołać się można do wspomnianej już cechy autentyczności, którą posiada prostowany na podstawie art. 18 akt normatywny, a której nie posiada (o czym szerzej niżej) jego tekst jednolity. Otóż, skoro tylko akt normatywny ogłoszony w określonym kształcie (tekst autentyczny) stanowi wyłączną podstawę rekonstrukcji wiążących jego adresatów wzorów zachowań, to zmiana jego treści w drodze sprostowania dostosowująca ją do tekstu oryginalnego, wszak wcześniej urzędowo nieogłoszonego i zasadniczo nieznanego jego adresatom $i$ wobec nich formalnie nieistniejącego (w sensie wpływu na ich sytuację prawna), nie może odnosić się do okresu sprzed oficjalnego, urzędowego sprostowania, ponieważ oznaczałoby to nadanie mocy prawnej nieautentycznemu (bo nieogłoszonemu) tekstowi aktu normatywnego, co należałoby uznać za sprzeczne nie tylko z wywodzoną z art. 2 Konstytucji RP zasadą zaufania i pewności prawa,

organy stanowiące j.s.t. teksty jednolite podlegają ogłoszeniu (ogłasza się je) w wydawanych przez wojewodów wojewódzkich dziennikach urzędowych.

${ }^{24} \mathrm{~W}$ orzecznictwie najwyraźniej pogląd ten wyraził NSA w wyroku z 6 lipca 1994 r., SA/Łd 1024/94, ONSA 1995, nr 4, poz. 159. 
ale również zasadą legalizmu (art. 7) oraz wynikającą z art. 88 ust. 1 zasadą warunkującą wejście w życie aktów zawierających przepisy powszechnie obowiązujące ich ogłoszeniem. Wejść w życie w kontekście tej zasady mogą zatem tylko zawarte $\mathrm{w}$ aktach normatywnych przepisy o treści, która została w przewidziany prawem sposób ogłoszona (teksty autentyczne).

Zasadniczo inaczej kwestia ta kształtuje się w przypadku tekstów jednolitych. Nie mają one bowiem waloru tekstów autentycznych ${ }^{25}$, a korzystają jedynie z domniemania autentyczności. Domniemania skądinąd szczególnego, ponieważ jego punktem odniesienia nie jest jeden akt normatywny, ale wszystkie akty - zarówno tekst aktu pierwotnego, jak i aktów dokonujących w nim zmian, stanowiących komponenty tekstu jednolitego. Przypomnieć przy tym należy, iż komponentami tekstu jednolitego są teksty autentyczne tych aktów, a zatem teksty urzędowo ogłoszone, pozostające $\mathrm{w}$ obrocie prawnym i wywołujące od momentu wejścia ich $\mathrm{w}$ życie określone skutki prawne w stosunku do podmiotów prawa, których sytuacja prawna w sposób bezpośredni lub pośredni kształtowana jest ich treścią. Stąd nie można zaakceptować tezy, że ich pominięcie lub zniekształcenie dokonane przy okazji ogłaszania tekstu jednolitego pozbawia bądź ogranicza ich moc prawną do czasu dokonania jego sprostowania. Jego skutkiem ma być bowiem wyłącznie uzgodnienie tego tekstu z tekstem zrekonstruowanym w oparciu o teksty autentyczne. Stąd teza o wywoływaniu przez obwieszczenia w sprawie sprostowaniu błędów w tekstach jednolitych skutków ex tunc. Odrębną kwestią jest przy tym, że z urzędowym charakterem ogłoszonego tekstu jednolitego przydającym mu znamię domniemania autentyczności (zgodności z tekstami aktów stanowiących jego komponenty) nierozerwalnie wiąże się pytanie o charakter tego domniemania w kontekście podmiotowych, proceduralnych i temporalnych aspektów jego obalenia.

Istnienie i funkcjonowanie (w znaczeniu praktycznego jej stosowania) instytucji tekstu jednolitego, zwłaszcza w kontekście łatwo dających się wyobrazić, nadto zaś przewidzianych przez prawodawcę przypadków wadliwie opracowanych (zredagowanych) i w takim kształcie ogłaszanych tekstów jednolitych ${ }^{26}$, kluczowym wręcz czyni zagadnienie charakteru i skutków prawnych ogłoszonego tekstu jednolitego ${ }^{27}$. Z teoretycznego i formalnego punktu widzenia sytuacja w tym zakresie zdaje się być w miarę jednoznaczna. Zarówno treść, jak i forma czynności, jaką jest ogłoszenie tekstu jednolitego, jednoznacznie sytuuje ją poza sferą prawotwórstwa. Jak stwierdzał K. Matuszewski, przez tekst jednolity nie można dokonywać żadnej materialnej zmiany w tekście aktu normatywnego, a tekst ten jest technicznym jedynie uporządkowaniem obowiązującego tekstu

${ }^{25} \mathrm{~W}$ tym zakresie podzielam pogląd P. Radziewicza (Radziewicz 2002, 59).

${ }^{26} \mathrm{Na}$ tym założeniu oparta jest instytucja sprostowania błędu w tekście jednolitym.

${ }^{27} \mathrm{Na}$ marginesie zakresu przedmiotowego niniejszego opracowania stwierdzić należy, iż zważywszy na przesłanki ogłaszania tekstów jednolitych aktów normatywnych i aktywność legislacyjną parlamentu, postawić można hipotezę, że w niedługim czasie zostaną ogłoszone teksty jednolite wszystkich niemal ustaw. 
aktu normatywnego (Matuszewski 1938, 31) ${ }^{28}$. Właściwie zredagowany tekst jednolity należy w tym sensie uznawać za rezultat czynności o walorze stricte deklaratoryjnym i stanowiąc wyłącznie źródło poznania prawa (informacji o aktualnej treści określonego aktu normatywnego), nie zawiera on jakichkolwiek nowości normatywnych (Wierczyński 2008, 263).

Deklaratoryjny, nieprawotwórczy i ogłaszany w szczególnej formie tekst jednolity nie może być jednak traktowany na równi z innymi źródłami informacji o prawie. Stanowi on bowiem informację (źródło poznania prawa) szczególną, co wynika przede wszystkim z jego urzędowego i stąd oficjalnego charakteru. Stanowiąc rezultat czynności konwencjonalnej podjętej przez właściwe organy władzy publicznej, w płaszczyźnie formalnej teksty jednolite skutkują wiążącą wszystkie podmioty prawa zmianą informacji o miejscu publikacji aktu normatywnego (staje się nim dziennik urzędowy, w którym zostało ogłoszone obwieszczenie w sprawie ogłoszenia tekstu jednolitego). Szerzej o skutkach tej zmiany pisze G. Wierczyński (Wierczyński 2015). Ważniejszy jest jednak skutek o charakterze merytorycznym, wyrażający się przyjęciem, że - jak już wspomniano - właściwie ogłoszony tekst jednolity korzysta $\mathrm{z}$ domniemania autentyczności, którego istotą jest wywodzone z jego urzędowego charakteru założenie, iż jego treść jest zgodna $\mathrm{z}$ tą jaką nadał mu prawodawca $\mathrm{z}$ uwzględnieniem treści aktów zmieniających, w konsekwencji stanowiąc wyłączny punkt odniesienia do stosowania danego aktu normatywnego.

W kontekście domniemania autentyczności pojawia się jednak pytanie o status niewłaściwie (błędnie) zredagowanego i ogłoszonego tekstu jednolitego, zwłaszcza w sytuacji, gdy rozbieżności między tekstem ogłoszonym a tekstem, który powinien być ogłoszony ${ }^{29}$, mają charakter merytoryczny, skutkując wprowadzeniem do tekstu jednolitego nowości normatywnych. Czy i kogo w takiej sytuacji tekst taki wiąże? Poglądy wyrażane w tej kwestii nie są jednoznaczne. $\mathrm{Z}$ jednej strony pojawiają się takie, które odwołując się do idei i charakteru tekstu jednolitego, kwestionują w takich przypadkach jego moc wiążącą. Przykładowo, zdaniem K. Matuszewskiego tekst jednolity nie znosi mocy obowiązującej pominiętych w nim norm prawnych ani nie nadaje umieszczonym, stąd włączenie do tekstu jednolitego zdania, którego ustawodawca nie ustanowił jako normy prawnej, nie udziela temu zdaniu cech tej normy. W konsekwencji sądy oraz niepodporządkowane organom ogłaszającym teksty jednolite organy administracji nie są nimi skrępowane i mogą badać zgodność tekstu jednolitego z tekstami nowel (Matuszewski 1938, 32). Niejednoznaczne stanowisko w tej kwestii zajmują autorzy komentarza do ZTP w zakresie aktów prawa miejscowego. Piszą oni bowiem, że w sytuacji rozbieżności między tekstem pierwotnym i jego nowelizacjami a tekstem jednolitym, należy stosować tekst pierwotny aktu z uwzględnieniem

${ }^{28}$ Mimo iż autor ten odnosił swoje ustalenia do ustaw, wydaje się, że nie na zasadniczych przeciwwskazań w zastosowaniu ich do tekstów jednolitych innych aktów normatywnych, w szczególności zaś aktów prawa miejscowego.

${ }^{29}$ Tekstem uwzględniającym wszystkie zmiany dokonane w akcie normatywnym. 
zmian wprowadzonych aktami zmieniającymi, a dostrzeżony błąd powinien zostać sprostowany. Dodają przy tym, iż „z drugiej strony jednak tekst jednolity aktu normatywnego jest objęty domniemaniem legalności", nie zajmując jasnego stanowiska (Szafrański, Białończyk, Bielecki, Kasiak, Piecha 2014, 216).

Wydaje się, że stanowisko aprobujące możliwość uwolnienia się od obowiązku uwzględniania urzędowo ogłoszonego tekstu jednolitego aktu normatywnego przez każdy podmiot (czy to organ władzy publicznej czy to podmiot prywatny), który stwierdzi wadliwość tego tekstu, jest zbyt daleko idące. Zagrożeniem dla poszanowania zasady pewności prawa, a także równości wobec prawa byłaby akceptacja sytuacji, w której ten sam akt normatywny funkcjonowałby w obrocie prawnym zarówno w wersji urzędowo ogłoszonego tekstu jednolitego, jak i uznanej za właściwą wersji ujednoliconej, do której odwoływałyby się podmioty kontestujące tekst jednolity.

Poszanowanie wskazanych wyżej wartości, przy jednoczesnym uznaniu powszechnie wiążącego (bo opartego na domniemaniu autentyczności) charakteru ogłoszonego tekstu jednolitego oraz oczywiście słusznym założeniu o niedopuszczalności wprowadzania jakichkolwiek zmian normatywnych przy okazji ogłaszania tego tekstu, pozwalają na wskazanie dwóch (co przy tym istotne - w przekonaniu autora - niealternatywnych) sposobów obalenia domniemania autentyczności niewłaściwego tekstu jednolitego. Pierwszym, skądinąd oczywistym, jest analizowana już instytucja sprostowania błędu w tekście jednolitym. Mimo sygnalizowanej odmienności od sprostowania błędu w ogłoszonym akcie normatywnym (stanowiącym podstawowy środek obalenia domniemania zgodności tekstu ogłoszonego z tekstem oryginalnym), nie ulega wątpliwości, że instytucja ta rolę tę spełnia. Sposób i forma sprostowania przesądzają przy tym o skuteczności obalenia domniemania erga omnes.

Drugim sposobem jest objęcie wadliwie sporządzonych tekstów jednolitych kontrola, w rezultacie której dojść może do uzasadnionego podważeniem jego prawidłowości wyeliminowania wadliwego tekstu jednolitego ze zbioru relewantnych prawnie źródeł informacji o prawie (w tym przypadku aktualnej na dzień ogłoszenia treści określonego aktu normatywnego). Rozwinięcie tego wątku wykracza poza ramy opracowania, podkreślić jednak należy podstawowe założenia tej koncepcji. Otóż, kluczowe miejsce zajmuje w niej przyjęcie, że wadliwie zredagowany i przez to wprowadzający nowe treści normatywne tekst jednolity nabiera waloru aktu normatywnego $\mathrm{w}$ znaczeniu materialnym (nie jest nim bowiem oczywiście w znaczeniu formalnym), skutkując możliwością objęcia go kontrolą ${ }^{30}$. W obowiązującym stanie prawnym założenie to zasługuje na aprobatę o tyle, że bez niego trudno byłoby znaleźć podstawy kontroli obwieszczeń

${ }^{30}$ Koncepcję aktu normatywnego w znaczeniu materialnym odniesioną do wadliwego materialnie tekstu jednolitego i umożliwiającego jego kontrolę wyraził Trybunał Konstytucyjny w orzeczeniu z 21 stycznia 1997 r. (K.18/96, OTK ZU 1997, nr 1, poz. 2). Spotkała się ona z aprobatą w literaturze przedmiotu (zob. np. Wierczyński 2008, 264; Radziewicz 2002, 66-67). 
w sprawie ogłoszenia tekstu jednolitego. Uogólniając problem, teksty jednolite jako takie (jako teksty aktów normatywnych uwzględniających dokonane w nich zmiany, stanowiące rezultat czynności o charakterze technicznym i porządkującym) kontroli nie podlegają. Odnosząc tę tezę do tekstów jednolitych samorządowych aktów prawa miejscowego, podkreślić należy, iż formalnie rzecz ujmując nie podlegają one nadzorowi, albowiem przewidziana przez u.o.a.n. forma wyłącza je z kategorii uchwał w rozumieniu przepisów określających przedmiotowy zakres nadzoru sprawowanego nad działalnością j.s.t. przez wojewodów oraz regionalne izby obrachunkowe (zob. art. 91 u.s.g., art. 79 u.s.p. i art. 82 u.s.w.). Również zakres kognicji sądów administracyjnych sprawujących kontrolę administracji publicznej, określony w art. 3 ustawy z dnia 30 sierpnia 2002 r. - Prawo o postępowaniu przed sądami administracyjnymi, nie obejmuje obwieszczeń w sprawie ogłoszenia tekstów jednolitych. Przyjęcie jednak, że zawierający nowość normatywną tekst jednolity stanowi akt normatywny w znaczeniu materialnym pozwala objać te teksty nadzorem i kontrolą sądową realizowaną w trybie i na zasadach właściwych dla aktów prawa miejscowego, których teksty jednolite zostały ogłoszone z uwzględnieniem specyfiki formalnego przedmiotu kontroli, jakim jest obwieszczenie w sprawie ogłoszenia tekstu jednolitego. Zważywszy na fakt, że wprowadzenie nowości w akcie prawa miejscowego w drodze takiego obwieszczenia jest absolutnie niedopuszczalne, skutkiem objęcia kontrolą takiego obwieszczenia zasadniczo powinno być stwierdzenie jego nieważności w całości.

W podsumowaniu raz jeszcze podkreślić należy, iż częste zmiany prawa uzasadniają potrzebę dostarczania adresatom regulacji prawnych aktualnej informacji o treści obowiązującego prawa. W obowiązującym stanie prawnym znajduje ona odzwierciedlenie przede wszystkim w regulacjach normujących instytucję tekstu jednolitego. Zważywszy przy tym na podkreślone w niniejszym opracowaniu znaczenie i prawne skutki ogłoszenia tekstu jednolitego aktu normatywnego (w szczególności aktu prawa miejscowego) ze wszech miar uzasadnionym czynią postulat powierzenia dokonywania działań w zakresie redagowania i ogłaszania tych tekstów podmiotom i osobom odpowiednio do tego przygotowanym. Ponadto, zwłaszcza wobec sygnalizowanego niebezpieczeństwa ogłaszania wadliwych tekstów jednolitych, konieczne jest również istnienie prawnych gwarancji właściwej realizacji kompetencji w tym zakresie, ze szczególnym uwzględnieniem objęcia ich kontrolą.

\section{BIBLIOGRAFIA}

Błachut, Michał, Włodzimierz Gromski, Jacek Kaczor. 2008. Technika prawodawcza. Warszawa: C.H. Beck.

Chmielnicki, Paweł. 2013. „Komentarz do art. 91”. W Ustawa o samorzqdzie gminnym. Komentarz. Red. Paweł Chmielnicki. LEX/el.

Garlicki, Leszek. 2002. „Kto prostuje błędy w tekście ustawy? Polemika z artykułem Piotra Radziewicza pt. «O sprostowaniu błędów w konstytucji i innych aktach prawnych»”. Przeglą Sejmowy 
2.

Malinowski, Andrzej. 2016. „Informacja o nieobowiązywaniu przepisu”. Przeglad Legislacyjny 1.

Matuszewski, Kazimierz. 1938. „Zagadnienie tekstów jednolitych”. Ruch Prawniczy, Ekonomiczny i Spoleczny 3 .

Radziewicz, Piotr. 2002. „O sprostowaniu błędów w konstytucji i innych aktach prawnych”. Przeglad Sejmowy 2.

Szafrański, Dariusz, Wojciech Białończyk, Andrzej Bielecki, Łukasz Kasiak, Jacek Piecha. 2014. Zasady techniki prawodawczej w zakresie aktów prawa miejscowego. Komentarz praktyczny z wzorami i przyktadami. Warszawa: C.H. Beck.

Wierczyński, Grzegorz. 2008. Urzędowe ogłoszenie aktu normatywnego. Warszawa: Wolters Kluwer. Wierczyński, Grzegorz. 2015. Udostęnianie informacji o prawie jako warunek skutecznej działalności prawotwórczej. LEX/el.

Wierczyński, Grzegorz. 2016. Redagowanie i ogłaszanie aktów normatywnych. Komentarz. LEX/el.

Wronkowska, Sławomira. 1996. „Glosa do wyroku NSA z dnia 6 lipca 1994 r., SA/Łd 1024/94”. Państwo i Prawo 3.

Wronkowska, Sławomira, Maciej Zieliński. 2002. Komentarz do Zasad techniki prawodawczej $z$ dnia 20 czerwca 2002 r. Warszawa: Wydawnictwo Sejmowe.

\title{
AKTY NORMATYWNE
}

Konstytucja Rzeczypospolitej Polskiej z dnia 2 kwietnia 1997 r. Dz. U. Nr 78, poz. 783 ze zm.

Rozporządzenie Prezesa Rady Ministrów z dnia 20 czerwca 2002 r. w sprawie „Zasad techniki prawodawczej”. Tekst jedn. Dz. U. 2016, poz. 283 (ZTP).

Ustawa z dnia 20 lipca 2000 r. o ogłaszaniu aktów normatywnych i niektórych innych aktów prawnych. Tekst jedn. Dz. U. 2016, poz. 296 (u.o.a.n.).

Ustawa z dnia 30 sierpnia 2002 r. - Prawo o postępowaniu przed sądami administracyjnymi. Tekst jedn. Dz. U. 2016, poz. 718 ze zm.

Ustawa z dnia 5 czerwca 1998 r. o samorządzie powiatowym. Tekst jedn. Dz. U. 2016, poz. 814 (u.s.p.).

Ustawa z dnia 5 czerwca 1998 r. o samorządzie województwa. Tekst jedn. Dz. U. 2016, poz. 486 (u.s.w.).

Ustawa z dnia 8 marca 1990 r. o samorządzie gminnym. Tekst jedn. Dz. U. 2016, poz. 446 (u.s.g.).

\section{Marek Lewicki}

\section{SELECTED ASPECTS OF TEXTS OF THE SELF-GOVERNMENTAL CONSOLIDATED STATUES OF LOCAL LAW}

\begin{abstract}
Practice of amending many times a statute gives rise to some problems in establishing binding contents of the statute. These problems should be eliminated by an institution of a consolidated text. This paper focuses on selected aspects of this legal institution with respect to statutes of local law. It explains regulations normalizing an obligation to announce these texts, their legal character as well as principles of eliminating errors occurring in them . It also emphasizes a necessity of due diligence when editing these texts in order to prevent consolidated texts from being against the binding law.
\end{abstract}

Keywords: consolidated text, correction of an error, local law, principles of the legislative technique, an amendment to a statute. 